\title{
Maximberus maxi n. gen., n. sp. from Southern and Southeastern Brazil (Diptera: Chironomidae, Orthocladiinae)
}

\author{
Trond Andersen ${ }^{1}$ \& Humberto Fonseca Mendes ${ }^{2,3}$ \\ ${ }^{1}$ Department of Natural History, University Museum of Bergen, University of Bergen, \\ P.O. Box 7800, N-5020, Bergen, Norway, e-mail: trond.andersen@um.uib.no \\ ${ }^{2}$ Centro de Ciências Naturais e Humanas - CCNH, Universidade Federal do ABC-UFABC, \\ Av. dos Estados, 5001, Bloco A, Torre 3, $6^{\circ}$ andar, Bangu, CEP 09210-580, Santo André, SP, Brazil \\ ${ }^{3}$ Corresponding author: Humberto Fonseca Mendes, e-mail: orthocladiinae@gmail.com
}

\begin{abstract}
ANDERSEN, T. \& MENDES, H.F. Maximberus maxi n. gen., n. sp. from Southern and Southeastern Brazil (Diptera: Chironomidae, Orthocladiinae). Biota Neotrop. 12(1): http://www.biotaneotropica.org.br/v12n1/ en/abstract?article+bn01512012012
\end{abstract}

\begin{abstract}
Maximberus maxi n. gen., n. sp. is described and illustrated based on adult males from Mata Atlântica in Southern and Southeastern Brazil. This genus can be separated from other Orthocladiinae on the combination of bare eyes, wing, and squama; no acrostichals; $\mathrm{R}_{4+5}$ ending proximal to $\mathrm{M}_{3+4}$; comb of setae on hind tibiae composed of few thin setae; well developed anal point; and virga composed of bundles of flattened spines attached to the oral part of the penis cavity.

Keywords: Chironomidae, Orthocladiinae, Maximberus, new genus, new species, Brazil, Neotropical region, Mata Atlântica.
\end{abstract}

ANDERSEN, T. \& MENDES, H.F. Maximberus maxi n. gen., n. sp. do sul e sudeste do Brasil (Diptera: Chironomidae, Orthocladiinae). Biota Neotrop. 12(1): http://www.biotaneotropica.org.br/v12n1/pt/ abstract?article+bn01512012012

Resumo: Maximberus maxi n. gen., n. sp. é descrita e ilustrada com base no macho adulto coletado na Mata Atlântica do sul e sudeste do Brasil. Este gênero pode ser separado dos demais Orthocladiinae com base na combinação de olhos, asas e squama sem pelos; setas acrosticais ausentes; $\mathrm{R}_{4+5}$ terminando proximal a $\mathrm{M}_{3+4}$; pente de setas na tíbia posterior composto por poucas setas finas; ponta anal bem desenvolvida; virga composta de um agrupamento de espinhos achatados fundidos a parte anterior da cavidade peniana.

Palavras-chave: Chironomidae, Orthocladiinae, Maximberus, gênero novo, espécie nova, Brasil, região Neotropical, Mata Atlântica 


\section{Introduction}

The number of orthoclad species known from Brazil has increased rapidly during the last decade. In their catalog of the Neotropical and Mexican chironomids Spies \& Reiss (1996) recorded seven Orthocladiinae species from Brazil; one of these, Ichthyocladius neotropicus Fittkau, as uncertain, a species which later has proved not to occur in Brazil (Mendes et al. 2004). Ten years later Mendes et al. (2007) listed 37 species of orthoclads, while today about 100 species are known to occur in Brazil (Mendes \& Pinho 2011). Several genera are so far only recorded from Brazil, viz. Gynocladius Mendes, Sæther et Andrade-Morraye, Iporangomberus Mendes et Andersen, Lyrocladius Mendes et Andersen, Oleia Andersen et Mendes, Saetherocladius Andersen et Mendes, Saetherocryptus Andersen et Mendes, Saetherolabis Andersen et Mendes, Saetherops Andersen et Mendes, and Ubatubaneura Wiedenbrug et TrivinhoStrixino, but a wider distribution of several of these genera is to be expected

However, a high number of new species still await description. When collecting in Brazil many of the orthoclads encountered do not readily fit into any described genus. Several of these might be terrestrial or semiterrestrial and the larvae and pupae might be difficult to locate. Below we describe the males of one of these species and place it in a new genus. The species was taken in Malaise traps in Mata Atlântica in Southern and Southeastern Brazil during the BIOTA-FAPESP project "Limites geográficos e fatores causais de endemismo na Floresta Atlântica em Diptera”.

\section{Material and Methods}

The specimens were mounted in Canada Balsam following the procedures outlined by Sæther (1969). The general morphology follows Sæther (1980). Measurements are given as ranges followed by the mean when four or more specimens were measured.

The types will be deposited in Museu de Zoologia da Universidade de São Paulo (MZUSP) and in the Department of Natural History, University Museum of Bergen, University of Bergen, Bergen, Norway (ZMBN).

\section{Maximberus n. gen}

Type species: Maximberus maxi $\mathrm{n}$. sp.

Etymology: Named after the senior author's one and a half year old grandson Max Rieber-Mohn for all interruptions while drawing the species; and Tupi mberui, midge, mosquito; meaning Max's midge. Gender of the genus name: masculine.

Diagnostic characters: The combination of bare eyes, wing, and squama; no acrostichals; $\mathrm{R}_{4+5}$ ending proximal to $\mathrm{M}_{3+4}$; comb of setae on hind tibiae composed of few thin setae; well developed anal point; and virga composed of bundles of flattened spines attached to the oral part of the penis cavity will separate the genus from all other orthoclads.

Description: Small sized species, wing length 0.70-0.94 mm.

Head. Eyes bare, reniform, without dorsomedian extension. Antenna with 12 flagellomeres; sparsely plumed; groove beginning on segment 2; sensilla chaetica present on flagellomeres 2, 3, and ultimate; without subapical seta. Palpomeres normal, third palpomere with few sensilla clavata subapically. Temporal setae in single row, inner verticals weak, outer verticals and postorbitals strong. Frontal tubercle absent. Tentorium and stipes normal. Cibarial pump with anterior margin weakly concave. Clypeus with few setae.

Thorax. Antepronotum well developed with lobes meeting medially at anterior margin of scutum. Acrostichals absent; dorsocentrals simple, uniserial; prealars uniserial; supraalar present. Scutellum with few setae in single row.

Wing. Membrane without setae, with fine punctuation, microtrichia visible at 400 times magnification. Anal lobe weakly developed. Costa extended; $\mathrm{R}_{2+3}$ running and ending midway between $\mathrm{R}_{1}$ and $\mathrm{R}_{4+5} ; \mathrm{R}_{4+5}$ ending proximal to $\mathrm{M}_{3+4} ; \mathrm{FCu}$ distal to $\mathrm{RM} ; \mathrm{Cu}_{1}$ slightly sinuous. Brachiolum with 1 seta, other veins bare. Squama bare. Sensilla campaniformia about 9 apically, 6 basally, and 3 above seta on brachiolum; 1 on RM; and 1 basally on $\mathrm{R}_{1}$.

Leg. Tibial spurs normal, comb of hind tibia composed of weak setae. Tarsal pseudospurs and sensilla chaetica absent. Pulvilli vestigial.

Abdomen. Abdominal setation reduced. Tergite I bare, tergites IIVIII with two irregular rows of few setae. Sternite I-III bare, sternite IV-VIII with few setae medially.

Hypopygium. Anal point well developed, tapering with rounded apex, with microtrichia and lateral setae. Tergite IX without setae; laterosternite IX with few setae. Apodemes well sclerotized. Phallapodeme with posterior, narrow, curved lobe; aedeagal lobe normal. Transverse sternapodeme arched, oral projections barely indicated. Penis cavity with horse-shoe shaped basal sclerite; virga consisting of 4-8 bundles of 1-4 separate, flattened spines attached to the penis cavity. Gonocoxite with weakly developed inferior volsella. Gonostylus curved, covered with microtrichia and with few setae; megaseta normal; crista dorsalis absent.

Female, pupa and larva. Unknown.

\section{Systematics}

The genus does not key to any specific genus either in Cranston et al. (1989) nor in Spies et al. (2009); in the former it will key to couplet 97 , if costa is considered to be not to moderately extended it will key to couplet 102; in the latter it will key to couplet 122.

The genus shows some similarities with Psilometriocnemus Sæther, especially the lack of acrostichals, bare wing membrane with fine punctuation, squama without setae, and anal point with lateral setae. However it can easily be separated from Psilometriocnemus based on the shape of the virga, absence of crista dorsalis, and $\mathrm{R}_{4+5}$ ending proximal to $\mathrm{M}_{3+4}$. A position in the group that includes the genera Heterotrissocladius Spärck, Parametriocnemus Goetghebuer, Paraphaenocladius Thienemann, Platysmittia Sæther and Psilometriocnemus Sæther does not seem unlikely.

\section{Maximberus maxi n. sp. (Figures 1-15)}

Type material: Holotype male: BRAZIL, Santa Catarina State, São Bento do Sul, 26 19' 25.6”' S and 48 $18^{\circ}$ ' 26.5”' W, 13-16.x.2001, $660 \mathrm{~m}$ a.s.l., Malaise trap (Trilha Rugendas 4), M.V. Yamada leg. (MZUSP). Paratypes: 3 males, same as holotype. 2 males, Santa Catarina State, Florianópolis, Unidade de Conservação Ambiental Desterro (U.C.A.D.), 03-20.xi.2003, Malaise trap, near stream, L.C. Pinho leg. 1 male, São Paulo State, Salesópolis, Estação Biológica Boracéia, Trilha dos Pilões, $23^{\circ} 39^{\prime} 01.9^{\prime \prime} \mathrm{S}$ and $45^{\circ} 53^{\prime} 36^{\prime \prime} \mathrm{W}$, 30.iii-02.iv.2001, Malaise trap (Mata 1), S.T.P. Amarante et al. leg. (BIOTA-FAPESP BORA09). 2 males, same as previous except for $23^{\circ} 39^{\prime}$ 03" S and 45 53' 36" W, 02-05.iv.2001, Malaise trap (Bosque 1), (BIOTA-FAPESP BORA06). 1 male, same as previous except for $23^{\circ} 39^{\prime} 06.3^{\prime \prime} \mathrm{S}$ and $45^{\circ} 53^{\prime} 48.9^{\prime \prime} \mathrm{W}$, Malaise (5) (BIOTA-FAPESP BORA15). 1 male, São Paulo State, Parque Estadual Intervales, Ribeirão Grande, Barra Grande, $24^{\circ} 15^{\prime} \mathrm{S}$ and $48^{\circ} 10^{\prime} \mathrm{W}, 10-13$. xii.2000, Malaise trap (Bosque 4), M.T. Tavares et al. leg. (BIOTAFAPESP PEIN03). 1 male, same as previous except for 13-16. xii.2000, Malaise trap (Trilha 5), (BIOTA-FAPESP PEIN09). 1 male, same as previous except for Malaise trap (Trilha 1), (BIOTA-FAPESP 

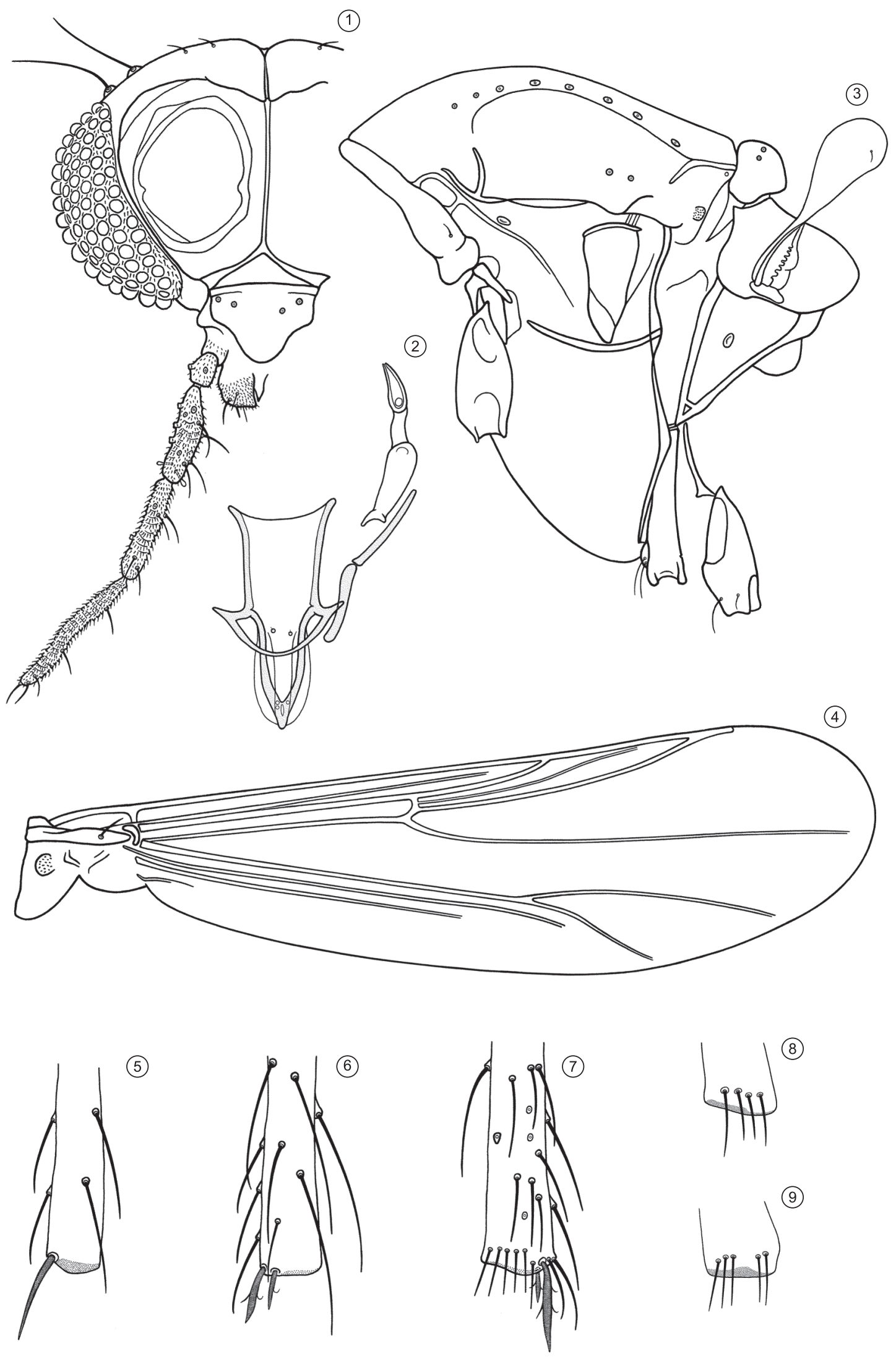

Figures 1-9. Maximberus maxi n. gen., n. sp., male. 1) Head; 2) Tentorium, stipes and cibarial pump; 3) Thorax; 4) Wing; 5) Apex of fore tibia; 6) Apex of mid tibia; 7) Apex of hind tibia; 8-9) Comb of setae of hind tibia. 

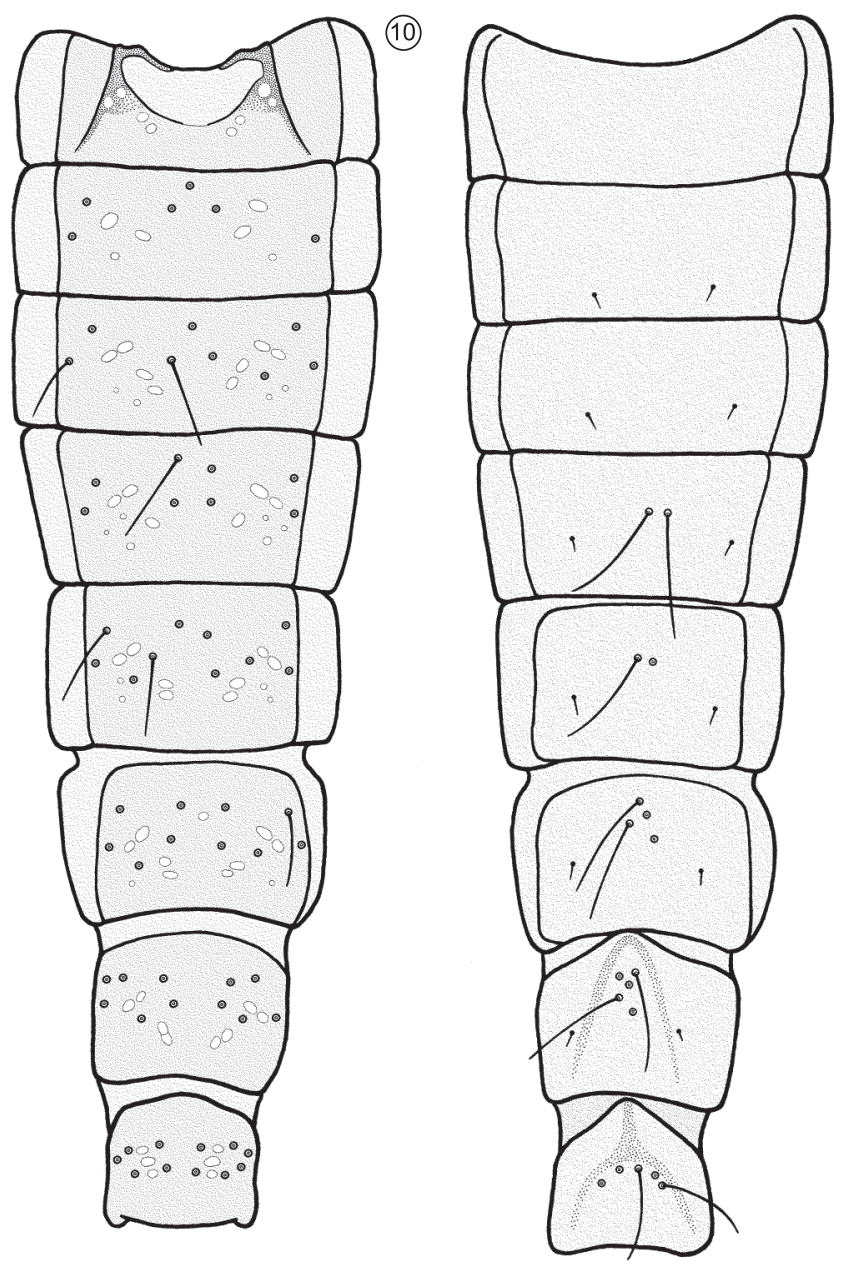

(11)

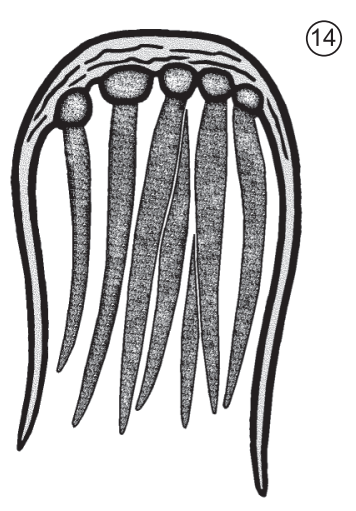

(14)
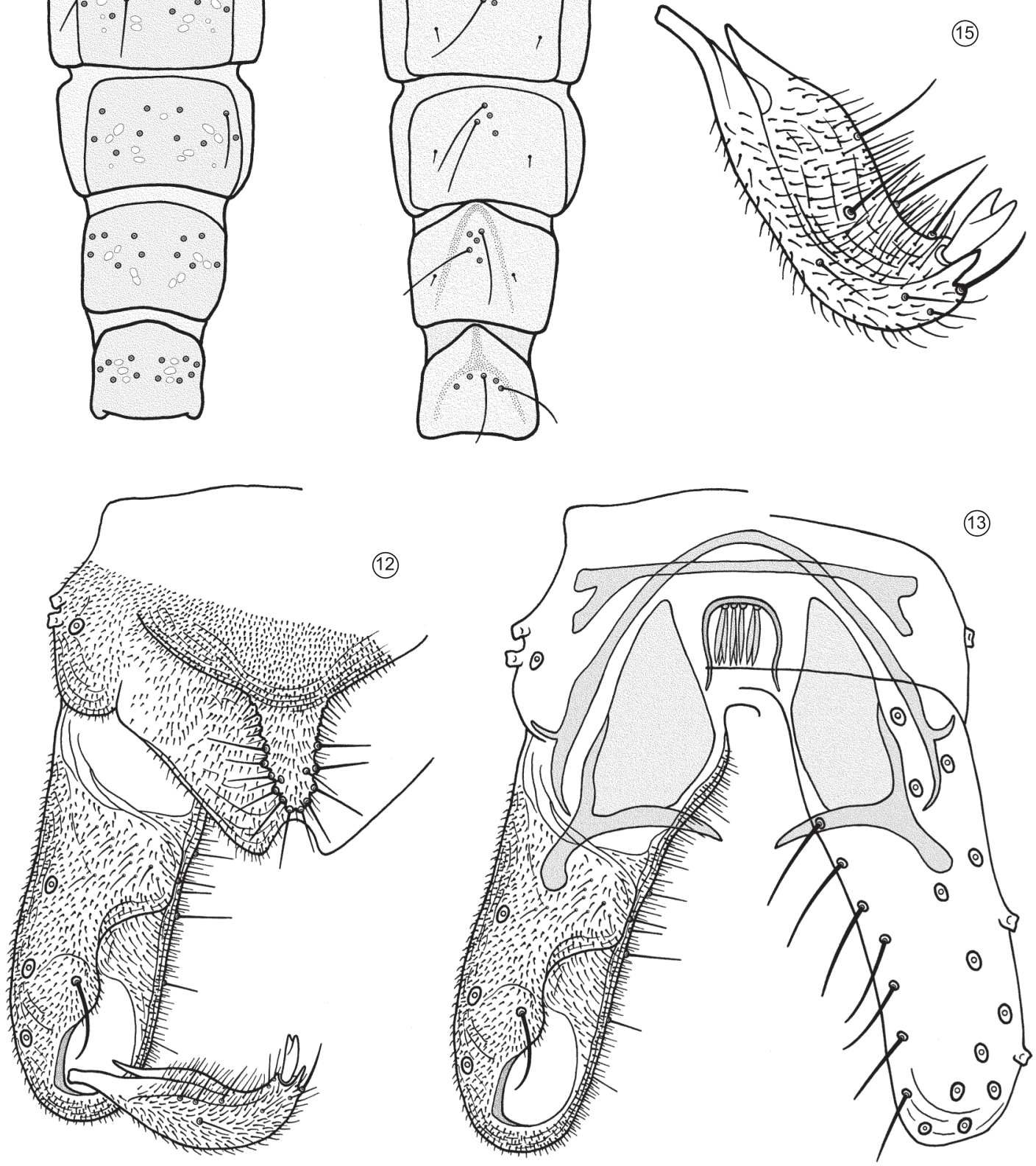

Figures 10-15. Maximberus maxi n. gen., n. sp., male. 10) Tergites I-VIII; 11) Sternites I-VIII; 12) Hypopygium, dorsal view; 13) Hypopygium with anal point and tergite IX removed, dorsal aspect to the left and ventral aspect to the right; 14) Virga; 15) Gonostylus, ventral view. 
Maximberus new genus

Table 1. Lengths (in $\mu \mathrm{m}$ ) and proportions of legs of Maximberus maxi $\mathrm{n}$. gen., $\mathrm{n}$. sp., male ( $\mathrm{n}=1-3$, except when otherwise stated).

\begin{tabular}{|c|c|c|c|c|c|c|}
\hline & fe & ti & $\mathrm{ta}_{1}$ & $\mathrm{ta}_{2}$ & $\mathrm{ta}_{3}$ & $\mathrm{ta}_{4}$ \\
\hline $\mathrm{p}_{1}$ & $248-360,300(8)$ & 286-403, 347 (8) & $130-212$ & $65-122$ & $47-65$ & $25-32$ \\
\hline $\mathrm{p}_{2}$ & 277-396, 207 (8) & $277-374,332(8)$ & 154 & 76 & 54 & 27 \\
\hline \multirow[t]{2}{*}{$\mathrm{p}_{3}$} & $266-385,334(8)$ & $277-389,350(8)$ & $151-198,177$ (4) & 83-104 & $72-90$ & $25-29$ \\
\hline & $\mathbf{t a}_{5}$ & $\mathbf{L R}$ & & & SV & BR \\
\hline $\mathrm{p}_{1}$ & $22-32$ & $0.40-0.57$ & & & $3.29-4.69$ & - \\
\hline $\mathrm{p}_{2}$ & 22 & 0.42 & 4. & & 4.70 & 4.0 \\
\hline $\mathrm{p}_{3}$ & $22-25$ & $0.45-0.51,0.48$ & & & $3.89-4.26$ & $6.4-6.8$ \\
\hline
\end{tabular}

PEIN10). 2 males, São Paulo State, Parque Estadual Serra do Mar,

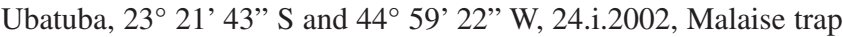
(Trilha 5), N.W. Perioto et al. leg. (BIOTA-FAPESP BRUB14). 1 male, same as previous except for Malaise trap (Trilha 1), (BIOTAFAPESP BRUB17). 1 male, same as previous except for 21.i.2002 Malaise trap (Bosque 9), (BIOTA-FAPESP BRUB13).

Etymology: The species is named after Max Rieber-Mohn, see etymology for genus name.

Diagnostic characters: see generic diagnosis.

Description: Male ( $\mathrm{n}=8-10$, except when otherwise stated). Total length 1.24-1.46, $1.35 \mathrm{~mm}$. Wing length 709-939, $835 \mu \mathrm{m}$. Total length/wing length 1.51-1.75, 1.60. Wing length/length of profemur 2.56-3.00, 2.82

Coloration. Thorax, head, and pedicel dark brown; abdomen, legs, and antennal flagellum slightly lighter brown; wings translucent.

Head (Figure 1). Antennae with 12 flagellomeres; AR 0.36-0.68, 0.46 ; ultimate flagellomere $115-220,160 \mu \mathrm{m}$ long. Temporal setae 5-7, 6 including 2-3, 3 inner verticals, 2-3, 3 outer verticals, and 1-2, 1 postorbital. Clypeus with 1-4, 3 setae. Tentorium, stipes, and cibarial pump as in Figure 2. Tentorium 54-84, $72 \mu \mathrm{m}$ long; 8-14, $11 \mu \mathrm{m}$ wide. Stipes 48-73, $57 \mu \mathrm{m}$ long. Palp segment lengths/widths (in $\mu \mathrm{m}$ ): 10$15,13 / 11-14,12$; 16-23, 19/10-14, 12; 50-60, 55/11-16, 13; 38-57, 41 (7)/9-11, 10 (7); 41-82, 50 (4)/7-9, 8 (4). Third palpomere with 2 sensilla clavata subapically; 7-10, $9 \mu \mathrm{m}$ long.

Thorax (Figure 3). Antepronotum with 1 seta. Dorsocentrals 7-11, 8; prealars 1-3, 2; supraalars 0-2, 1. Scutellum with 3-6, 4 setae.

Wing (Figure 4). VR 1.34-1.61, 1.46. Costal extension 27-61, $43 \mu \mathrm{m}$ long. Brachiolum with 1 seta, remaining veins and cells bare. Squama bare.

Legs (Figures 5-9). Spur of fore tibia 21-27, $25 \mu \mathrm{m}$ long; spurs of mid tibia 11-23, $16 \mu \mathrm{m}$ and 9-16, $12 \mu \mathrm{m}$ long; spurs of hind tibia 20$27,23 \mu \mathrm{m}$ and 10-14, $12 \mu \mathrm{m}$ long. Width at apex of fore tibia 14-18, $16 \mu \mathrm{m}$; of mid tibia 16-18, $17 \mu \mathrm{m}$; of hind tibia 18-23, $21 \mu \mathrm{m}$. Comb with 6-7, 6 setae; longest 16-20, $18 \mu \mathrm{m}$ long; shortest 9-16, $13 \mu \mathrm{m}$ long. Lengths and proportions of legs as in Table 1.

Abdomen (Figures 10-11). Strong setae on tergites I-VIII as: 0; 6-8, 7; 4-8, 7; 6-11, 7; 6-12, 9; 6-13, 10; 6-18, 11; 6-16, 10. Strong setae on sternites I-VIII as: $0 ; 0 ; 0 ; 2 ; 2-3,2 ; 2-4,3 ; 2-5,4 ; 4-7,5$.

Hypopygium (Figures 12-13). Anal point covered with microtrichia; with 8-16, 12 marginal setae; 16-27, 23 um long; 14-23, $17 \mu \mathrm{m}$ wide at base. Tergite IX without setae; laterosternite IX with 1-4, 3 setae. Transverse sternapodeme 38-59, $48 \mu \mathrm{m}$ long. Phallapodeme 39-53, $48 \mu \mathrm{m}$ long; with posterior, 29-38, $34 \mu \mathrm{m}$ long, curved lobe. Virga (Figure 14) with 4-8, 5 bundles of spines, each with 1-4 flattened, 10-16, $13 \mu \mathrm{m}$ long spines. Gonocoxite 73-104, $93 \mu \mathrm{m}$ long. Gonostylus (Figure 15) 38-50, $46 \mu \mathrm{m}$ long; megaseta 4-8, $6 \mu \mathrm{m}$ long, with a cleft apically. HR 1.67-2.33, 2.03. HV 2.53-3.03, 2.86.

\section{Distribution and Habitat}

The species is known from São Paulo and Santa Catarina States where it was collected in Malaise traps in five nature reserves. A wider distribution can be expected as it occurs at lower altitudes in the so called Serra do Mar endemism subregion of the Mata Atlântica (Silva \& Casteleti 2003). It was taken in areas showing different degrees of forest succession varying from almost completely open areas to pristine forests. Most of the areas are covered with low ground vegetation and epiphytes are abundant on tree trunks. Small rivers and springs occur in all the reserves where the species was taken.

\section{Acknowledgements}

We are indebted to Dr. Carlos J. E. Lamas, Museu de Zoologia, Universidade de São Paulo and to Dr. Dalton S. Amorim, Faculdade de Filosofia Ciências e Letras de Ribeirão Preto, Universidade de São Paulo campus Ribeirão Preto for the loan of specimens from the BIOTA-FAPESP project ["Limites geográficos e fatores causais de endemismo na Floresta Atlântica em Diptera" proc. 03/12074-9 within The Biodiversity Virtual Institute Program (www.biota.org)]. Thanks are also due to Dr. Luiz C. Pinho, Universidade Federal de Santa Catarina for making the material collected in Santa Catarina available to us. Gladys Ramirez made the slide preparations. The study was partially funded by FAPESP (11/50162-1), partially by the University Museum of Bergen.

\section{References}

CRANSTON, P.S., OLIVER, D.R. \& SÆTHER, O.A. 1989. The adult males of Orthocladiinae (Diptera: Chironomidae) of the Holarctic region. Keys and diagnoses. In Chironomidae of the Holarctic region. Keys and diagnoses. Part 3. Adult males (T. Wiederholm, ed.). Entomol. Scand. 34(Suppl.): 165-352.

MENDES, H.F. \& PINHO, L.C. 2011. Brazilian chironomid home page. http:// sites.google.com/site/brazilianchironomids/ (ultimo acesso 22/12/2011).

MENDES, H. F., ANDERSEN, T. \& PINHO, L.C. 2007. Taxonomic research on Brazilian Orthocladiinae (Diptera: Chironomidae) during the last decade. Entomol. Mex. 6:1173-1177.

MENDES, H.F., ANDERSEN, T. \& SÆTHER, O.A. 2004. New species of Ichthyocladius Fittkau, a member of the Corynoneura-group (Diptera: Chironomidae: Orthocladiinae), with a review of the genus. Stud. Neotrop. Fauna Environ. 39:15-35. http://dx.doi.org/10.1080/0165052 0412331270936

SÆTHER, O.A. 1969. Some Nearctic Podonominae, Diamesinae and Orthocladiinae (Diptera: Chironomidae). Bull. Fish. Res. Board Canada 107:1-154. 
SÆTHER, O.A. 1980. Glossary of Chironomid morphology terminology (Diptera: Chironomidae). Entomol. Scand. 14(Suppl.):1-51.

SILVA, J.M.C. \& CASTELETI, C.H.M. 2003. Status of the Biodiversity of the Atlantic Forest of Brazil. In The Atlantic Forest of South America: Biodiversity Status, Threats, and Outlook (C. Galindo-Leal \& I.G. Câmara, eds). Island Press, Washington, p. 43-59.
SPIES, M. \& REISS, F. 1996. Catalog and bibliography of neotropical and Mexican Chironomidae (Insecta, Diptera). Spixiana 22(Suppl.):61-119. SPIES, M., ANDERSEN, T., EPLER, J.H. \& WATSON JUNIOR, C.N. 2009. Chironomidae (Non-biting midges). In Manual of Central American Diptera (B.V. Brown, A. Borkent, J.M. Cumming, D.M. Wood, N.E. Woodley \& M.A. Zumbado, eds). NRC Research Press, Ottawa, p.437480 .

Received 23/12/2011

Revised 14/02/2012

Accepted 02/03/2012 